\title{
Psicologia, tecnologia e comportamento humano: 0 caso do turismo virtual imersivo, uma alternativa sustentável ao turismo convencional
}

\section{Psychology, technology and human behaviour: The case of immersive virtual tourism, a sustainable alternative to conventional tourism}

Segundo a Organização Mundial do Turismo, em 2019 registou-se um número total de 1.4 mil milhões de turistas internacionais, que representaram um volume de negócios ligado ao sector de cerca de 1426 mil milhões de euros. Sendo que a indústria do turismo envolve diversos atores, desde os próprios turistas passando pelos operadores turísticos até as entidades responsáveis pelos pontos turísticos de interesse, este alto volume de turismo torna evidente dois problemas que dele advêm: (1) com o elevado número de destinos turísticos, torna-se mais desafiante criar estratégias de marketing que diferenciem determinadas ofertas turísticas das demais e; (2) o alto volume turístico acarreta uma sobrecarga aos recursos dos próprios destinos turísticos, pondo a sua sustentabilidade em causa.

No que diz respeito ao primeiro ponto, a criação de produtos de marketing diferenciadores para a promoção de destinos turísticos, a Realidade Virtual pode ter um papel importante na medida em que os atuais meios de marketing de destinos turísticos baseiam-se em brochuras e vídeos promocionais. Apesar destes meios promocionais serem importantes para esclarecer o turista em relação ao que pode encontrar no destino turístico, o seu impato é limitado e perde-se pela grande quantidade de informação disponível acerca dos diferentes destinos turísticos disponíveis. Tirando partido da natureza imersiva da realidade virtual, podemos utilizar esta tecnologia para apresentar conteúdos promocionais sobre um determinado local turístico e, ao mesmo tempo, conferindo aos potenciais turísticas um sentimento de estarem a ser transportados para ele local e, por momentos, fazê-los sentir como se lá estivessem. Este fator, só por si, já pode ser considerado uma melhoria em relação aos demais métodos promocionais. No entanto, existe mais um fator que pode ser explorado de forma a criar uma experiência mais marcante e despertar emoções e ligações aos destinos turísticos, aumentando o interesse dos potenciais turistas em visitar as zonas retratadas: a utilização de estímulos multissensoriais em experiências de realidade virtual imersiva. Para além destes conteúdos multissensorias de realidade virtual imersiva poderem dar ao utilizar um vislumbre do que é realmente estar no local turístico, outros mecanismos interativos podem ser incluídos tais como informações adicionais e serviços digitais que incentivem o desejo de consumo, fazendo com que os produtos turísticos sejam mais apelativos e, assim, adquiridos.

Tendo em atenção a sobrecarga dos recursos dos próprios destinos turísticos, é também importante salvaguardar o patri- 
mónio cultural de forma a que ele seja conservado da melhor forma possível. Imaginemos monumentos históricos como as pirâmides do Egito, Machu Picchu ou a grande muralha da China: devido ao número de visitantes anuais, o seu desgaste é tal que a sua integridade está em risco. O recurso a estações de realidade virtual que estariam, idealmente, localizados em pontos estratégicos próximos ao ponto de interesse turístico em causa e que permitissem uma visita guiada virtual imersiva e multissensorial pode ser uma ferramenta importante a considerar por entidades responsáveis pelos pontos turísticos de interesse de forma a diminuir o número de acessos físicos a esses mesmos pontos, protegendo-os da pressão turística.
Apesar de todas estas propostas serem ambiciosas, altamente inovadoras e com muito potencial de mercado, existe ainda um percurso interessante a fazer no ponto de vista de avaliação destas tecnologias do ponto de visto do utilizador. Para além disso, é sempre crucial fazer o balanço entre as expetativas potencial turista e a possibilidade das aplicações de realidade virtual substituírem a necessidade de visita ao ambiente real. Assim, esta linha de atuação tecnológica abre portas a linhas de investigação na área da psicologia e comportamento humano de forma a identificar quais serão as melhores e mais eficazes abordagens para fazer com que estas tecnologias sejam tecnologias de sucesso no mercado turístico. 